\title{
A GÉPÉSZKAROKON TANULÓ HALLGATÓK VÁLLALKOZÁSALAPÍTÁSI MOTIVÁCIÓI
}

\begin{abstract}
A szerzố dolgozatában magyar gépészhallgatók vállalkozásalapítási hajlandóságát ismerteti. A cikk megállapításai egy 2007-ben lefolytatott kérdő́ives vizsgálaton alapulnak. A felmérés mintájául hét fóvárosi felsóoktatási intézmény szolgált. ${ }^{1}$ A vizsgált intézmények közül háromnak van valamilyen gépészkara. A cikkben a szerzố a gépészkarok hallgatóinak vállalkozásalapítási szándékaira koncentrál a teljes sokaság jellemzóivel összehasonlítva.
\end{abstract}

\section{Kulcsszavak: vállalkozásalapítás, gépészhallgatók}

2008 utolsó hónapjaiban a recessziós félelmek hatására hatványozottan erősödtek meg azok a hangok, amelyek a hazai kis- és középvállalkozások kisegítését, fokozottabb támogatását célzó gazdaságpolitika folytatását szorgalmazzák. Politikusok és érdekképviseleti szervek szerint támogatott beruházási hitelek, adókedvezmények és egyéb, a munkahelyek megôrzését segító támogatások szükségesek. Mások szerint viszont nincs semmi gond a világgazdaságban, a piac egyszerúen megtisztítja önmagát (,,business as usual”). A válság remek alkalmat teremt az innovációra, valamint arra, hogy a csôdbe menố vállalatok helyét új, versenyképesebb cégek vegyék át. Ezekkel az elképzelésekkel mindenki - gazdaságideológiai beállítottságától függően - különbözô mértékben érthet egyet.

Azzal azonban nehéz vitatkozni, hogy ebben a gazdasági helyzetben tényleg csak az alkalmazkodóképesebb cégek maradhatnak életben. De az abszolút számokon túl legalább olyan fontos az is, hogy a közép- és hoszszú távon számos új munkahelyet teremtő, a gazdasági és - sok esetben a technológiai - megújulás hajtóerejét képező új, innovatív kisvállalkozások száma hogyan alakul (GEM, 2004). Az USA-ból számos példa hozható, hogy ezek a „garázscégek” rövid idő alatt, a piaci réseket kihasználva, vagy éppen a piac és technológia számára egyaránt újdonságot jelentố komplex megoldásokat bevezetve váltak elóbb országos, majd világméretû́ céggé. Ezeket a cégeket sok esetben karrierjük elején álló egyetemista és fóiskolai hallgatók alapították, akik esetleg még tanulmányaikat sem fejezték be. Az amerikai gazdasági és társadalmi környezetben ez a fajta mentalitás egyáltalán nem szokatlan, Magyarországon azonban ,ritka, mint a fehér holló” az ilyen hallgató. De vajon mennyiben állja meg a helyét ez az állítás?

\section{Fơhipotézisek és kutatási kérdések}

Feltevésünk szerint a hallgatók motivációja karonként és szakterületenként eltérô, ez a hipotézis befolyásolta mintaválasztásunkat leginkább. Elsôsorban az informatikai, múszaki és természettudományi karok érdekeltek bennünket, hiszen ezeken a karokon nagyobb számban fordulhatnak elő olyan hallgatók, akik a megszerzett tudásra, vagy valamilyen saját tudományos eredményre (publikáció, esetleg szabadalom) alapozva érdekelté vállnak a saját vállalkozás alapításában. Mindezt a külföldi példák is alátámasztják, hiszen a bevezetőben említett „garázscégek” elsôsorban ezeken a területeken alakultak és alakulnak ma is. Ezzel párhuzamosan feltételeztük azonban azt is, hogy a hazai hallgatók vállalkozási motivációi eltérnek az amerikai mintától.

A kutatás egyik alapvető feladatának tekintettük, hogy az egyetemi hallgatók által alapított, már létező vállalkozásokat, és azok innovációs teljesítményét feltérképezzük, valamint egyetem utáni vállalkozásalapításra vonatkozó terveikról is képet kapjunk. Kíváncsiak voltunk arra is, hogy milyen ismeretek megléte lenne szükséges a vállalkozásindításhoz. 
A fentieken túl a gépész karokkal kapcsolatban egy speciális feltevést is meg kell vizsgálni. A HVG felsőoktatási különszáma által közölt piaci rangsor szerint legnagyobb presztízsúnek a BME-kara tekinthetô, a második helyen a BMF-kara található, míg a SZIE gépészkara csupán harmadik (HVG, 2008). A gépészmérnököket keresố álláshirdetések $61 \%$-át multinacionális cégek adják fel, az összes mérnöki diplomás állás esetén ugyanez az arány csak $46 \%$. A három képzési környezet más-más vállalkozásalapítási motivációkat feltételez. A gépészek keresettebbnek tekinthetôk a magas kezdô fizetést biztosító multinacionális cégeknél, mint a mérnökök általában. Ezt a tényt, valamint a piaci rangsort ismerve, feltételezhetjük, hogy a magasabb presztízsú diplomával rendelkezó, frissen végzett gépészhallgatók kevesebb motivációt fognak érezni a vállalkozásalapításra, sốt már tanulmányaik során is más életpályát szánnak maguknak. A BME-piacon értékesebb diplomája jobb lehetőséget biztosít egy multinacionális cégnél való elhelyezkedésre, így a hallgatók számára a vállalkozói lét kevésbé vonzó.

\section{A kérdőív módszertana és felépítése}

A kutatásba hét fơvárosi felsőoktatási intézmény kiválasztott karainak elemzése hagyományos statisztikai eszközökkel, valamint SPSS segítségével történt. Az adatfelvételt on-line kérdőívvel végeztük. A kérdőív alapvetóen strukturált, zárt kérdéseket tartalmazott, a kérdések kisebbik része igényelt csak mennyiségi válaszokat. A kérdőív végén lehetőséget biztosítottunk a pluszinformációt hordozó vélemények kifejtésére. Ezzel a módszerrel aránylag rövid idő alatt, ugyanakkor költségkímélő módon lehetővé vált, nagy számú hallgató elérése a hét felsőoktatási intézmény különböző karain ${ }^{2}$. A válaszadók anonimitását biztosítottuk, aminek valószínúsíthetően pozitív a hatása a válaszadói hajlandóságra.

A kutatásba bevont egyetemi karok dékáni hivatalaitól, tanulmányi osztályaitól, illetve ott dolgozó kollégáktól kértünk segítséget a kérdôív hallgatókhoz való eljuttatásában. A kísérólevelet, amely a kitöltésre való felhíváson túl, tartalmazta a kérdôívre mutató on-line hivatkozást is, a hallgatóknak e-mailben, a tanulmányi rendszeren (a legtöbb helyen ez a NEPTUN volt) keresztül üzenetként küldtük el, illetve több helyütt felkerült a kari honlapokra és egyéb egyetemi, kari információs oldalakra. Rendszeres idóközönként további emlékeztetô üzeneteket küldtünk a hallgatók számára a kutatásban való részvételre.

A megcélzott sokaság elérésének nehézségét jelentette, hogy a kérdőív csak azokhoz a hallgatókhoz jutott el idôben, akik gyakran látogatják felsőoktatási intézményük hírportálját, használják azt az e mail címüket, amellyel az intézményük levelezólistáin szerepelnek.

A kérdések elsó blokkja a hallgatók jellemző alapadataira vonatkozott. A második kérdésblokk a diákok egyetemi tevékenységét firtatta. A harmadik kérdéscsoport a vállalkozási és munkatapasztalatot tudakolta. A negyedik blokk volt vizsgálatunk szempontjából a legizgalmasabb. Az iránt érdeklődött, hogyha a hallgató vállalkozást alapítana, akkor (1) milyen gazdasági területen hozná létre, (2) kiktól kérne szakmai segítséget, (3) milyen forrásból próbálná megszerezni a szükséges alaptő́két, (4) milyen szolgáltatásokra lenne szüksége, valamint (5) igénybe venne-e egyetemi segítséget. Majd az ötödik kérdésblokk arra kért választ, hogy a felsôoktatási intézmény milyen területen tudna segíteni a vállalkozásalapítás során, ideértve az oktatást, a fontosnak tartott kurzusok témáját is. Végezetül a hallgatók vállalkozói léttel kapcsolatos attitúdjére voltunk kíváncsiak, arra hogy, mennyire szívesen követnék ezt az életutat.

\section{A cikkben vizsgált minta jellemzói}

Az on-line kérdőívre összesen 1622 értékelhetô válasz érkezett, ebból 238 a gépészkarok hallgatóitól. A válaszadók közel 60\%-a (966 fó) férfi volt (1. táblázat).

1. táblázat

A teljes minta válaszainak megoszlása

\begin{tabular}{|l|c|c|}
\hline \multicolumn{1}{|c|}{ Intézmény neve } & $\begin{array}{c}\text { A válasz- } \\
\text { adók aránya } \\
(\boldsymbol{\%})\end{array}$ & $\begin{array}{c}\text { Hallgatói } \\
\text { létszám } \\
\mathbf{2 0 0 6 / 2 0 0 7 - e s} \\
\text { tanévben }\end{array}$ \\
\hline Budapesti Corvinus Egyetem & 45 & 10059 \\
\hline Szent István Egyetem & 22 & 7581 \\
\hline Bp-i Múszaki és Gazdaságtud. E. & 15 & 16453 \\
\hline Budapesti Múszaki Főiskola & 8 & 8216 \\
\hline Pázmány Péter Katolikus Egyetem & 5 & 4960 \\
\hline Eötvös Loránd Tudományegyetem & 4 & 20489 \\
\hline Semmelweis Egyetem & 2 & 6154 \\
\hline Összesen: & $\mathbf{1 0 0}$ & $\mathbf{7 3 9 1 2}$ \\
\hline
\end{tabular}

A gépészek képzése Budapesten a Szent István Egyetem (SZIE) és a Budapesti Múszaki és Gazdaságtudományi Egyetem (BME) egyetemi, valamint a Budapesti Mú́szaki Fớiskola fơiskolai karán történik. A gépészkarokról 238 válasz érkezett, vagyis az összes válasz $15 \%$-a. Sajnos itt is megfigyelhetô az a probléma, ami a teljes mintát is jellemzi, miszerint a beérkezett válaszok száma - az egyes karok tekintetében - nem 
egyenletes. Jelen esetben ez azt is jelenti, hogy a legtöbb válasz a „legkisebb" gépészkarról érkezett, míg a legkevesebb a legnagyobbról, vagyis a sorrend megfordult ${ }^{3}$. A 2. táblázat a válaszok megoszlását mutatja.

2. táblázat

A gépészkarok válaszainak megoszlása

\begin{tabular}{|l|c|c|}
\hline \multicolumn{1}{|c|}{ Gépészkarok } & $\begin{array}{c}\text { Válaszok } \\
\text { száma }\end{array}$ & $\begin{array}{c}\text { A válaszok } \\
\text { aránya }(\boldsymbol{\%})\end{array}$ \\
\hline BME Gépészmérnöki Kar & 30 & 13 \\
\hline BMF Bánki D. Gépészmérnöki Kar & 67 & 28 \\
\hline SZIE Gépészmérnöki Kar & 141 & 59 \\
\hline Összesen & $\mathbf{2 3 8}$ & $\mathbf{1 0 0}$ \\
\hline
\end{tabular}

A beérkezett válaszok alapján a hallgatók a vállalkozással való kapcsolatuk alapján három nagyobb csoportra oszthatók. Az egyik csoportba tartoznak azok, akiknek már van vállalkozásuk. Szám szerint ók vannak a legkevesebben. A második csoportba tartoznak azok, akiknek nincs vállalkozásuk, de szeretnének, a harmadikba pedig azok, akiknek nincs vállalkozásuk és nem is szeretnének. A válaszadók csoportosítását a 3. táblázat tartalmazza.

3. táblázat

A hallgatók vállalkozással kapcsolatos attitúdje

\begin{tabular}{|l|c|c|c|c|}
\hline & \multicolumn{2}{|c|}{ Gépészhallgatók } & \multicolumn{2}{c|}{ Összes hallgató } \\
\hline $\begin{array}{c}\text { Vállalkozáshoz } \\
\text { való viszony }\end{array}$ & $\begin{array}{c}\text { válasz- } \\
\text { adók } \\
\text { száma }\end{array}$ & $\begin{array}{c}\text { válasz- } \\
\text { adók } \\
\text { aránya } \\
(\%)\end{array}$ & $\begin{array}{c}\text { válasz- } \\
\text { adók } \\
\text { száma }\end{array}$ & $\begin{array}{c}\text { válasz- } \\
\text { adók } \\
\text { aránya } \\
(\%)\end{array}$ \\
\hline Van vállalkozása & 15 & 6 & 114 & 7 \\
\hline $\begin{array}{l}\text { Nincs vállalkozása, } \\
\text { de tervezi }\end{array}$ & 99 & 41 & 568 & 35 \\
\hline $\begin{array}{l}\text { Nincs vállakozás és } \\
\text { nem is tervezi }\end{array}$ & 124 & 52 & 940 & 58 \\
\hline Összesen & $\mathbf{2 3 8}$ & $\mathbf{1 0 0}$ & $\mathbf{1 6 2 2}$ & $\mathbf{1 0 0}$ \\
\hline
\end{tabular}

A 3. táblázatból látható, hogy a választ adó hallgatók 58\%-ának nincs vállalkozása, és nem is tervezi alapítását. Ennél jóval kisebb azok aránya (35\%) akiknek még nincs vállalkozásuk, de tervezik annak alapítását. A kérdőív csak arra kérdezett rá, hogy tulajdonosa-e valamilyen vállalkozásnak, azt azonban nem firtatta, hogy az milyen szakterületen tevékenykedik. Így aztán a családi vállalkozásban résztulajdonos hallgató is igennel válaszolt. A válaszokat érdemes a csoportképzó ismérvek szerint feldolgozni, hiszen feltételezhető, hogy az egyes csoportok bizonyos kérdéseket másképpen ítélnek meg.

\section{A kérdốív fóbb eredményei}

A vállalkozásalapítási hajlandóság összefüggései Előzetes hipotézisünket az eredmények tehát visszaigazolták, hiszen a válaszadóknak csak kicsit több, mint a fele zárkózik el a vállalkozói életpályától (58\%). A helyzet egy kicsit rosszabb a gépészek esetében (52\%), ez a különbség azonban korántsem szignifikáns. A kérdést az egyes gépészkarok szerint külön-külön elemezve nem tapasztalható lényeges eltérés, a megkérdezetteknek mindenhol közel, vagy csak egészen kicsit több, mint a fele tervezi úgy, hogy vállalkozást alapít. A legkevesebben a SZIE Gépészkarán, a legtöbben pedig a BME Gépészkarán alapítanának vállalkozást.

A gépészhallgatók közül 117 nyilatkozott úgy, hogy a családjában (szüloók, nagyszülók, egyéb rokonok) van vállalkozás. Ennek a 117 fónek a 60\%-a tervezi, hogy a késóbbiekben vállalkozást alapít. A teljes sokaság esetében ez az arány 54\%. A vállalkozó családtag, mint családi minta növeli annak szándékát, hogy a hallgató is vállalkozói pályára lép.

A vállalkozással rendelkező 15 gépészhallgató között a BME hallgatóinak aránya (13\%) a legmagasabb, jóval a gépészek és a teljes sokaság átlagát -6 , illetve $8 \%$-meghaladó arányban rendelkeznek vállalkozással.

Meg kell jegyezni azonban, hogy a BME-ról érkezett a legkevesebb válasz, csupán harminc. Feltételezve, hogy a nem válaszolás is információ, vagyis a $13 \%$ os válaszadási arány oka lehet az is, hogy a hallgatók többsége nem érdeklődik a vállalkozásindítással kapcsolatos kérdőív iránt, ezért nem tartották fontosnak azt kitölteni.

A megkérdezettek véleménye szerint egy vállalkozás indítását az egyetem leginkább üzleti és jogi tanácsadással tudná segíteni, vagyis a hallgatók ezeket a szolgáltatásokat vennék igénybe elsősorban. Az egyetem anyagi segítségére azonban nem számítanak, ahogy az innováció és $K+F$-menedzselési tanácsadásra sem. Hasonló a helyzet, ha a szükséges ismereteket nézzük. Legszükségesebbnek az általános vállalkozási ismereteket, valamint az üzleti tervezést ítélték, míg legkevésbé az innováció és a $\mathrm{K}+\mathrm{F}$ menedzselési ismeretekre tartottak igényt. Az innováció és $\mathrm{K}+\mathrm{F}$ menedzsment megítélése a gépészek csoportját nézve sem változik, sốt kevesebb említést kaptak, mint a teljes sokaság átlaga. Ennek okait a következókben kicsit részletesebben is vizsgáltuk.

\section{Innovatív kisvállalkozások?}

A teljes sokaság esetében a 117 vállalkozásból 24 végez K+F-tevékenységet, s közülük 23 már ,valamilyen újdonságot" is kifejlesztett, vagyis a vállalkozások 
20\%-a „született” azért, mert alapítója valamiféle tudományos, technológiai eredményt hasznosított. Ezek után nem csoda, hogy nem, vagy alig igénylik az innováció és $\mathrm{K}+\mathrm{F}$-menedzselési ismereteket, mert nem ilyen orientációjú vállalkozásokat múködtetnek, vagy kívánnak alapítani. Ha van is vállalkozási szándék, az nem a klasszikus egyetemi spin-off vállalkozások alapítására irányul. Az egyik válaszadó fogalmazása szerint: „ez nem az a szakma, amiben egyedül alkothat az ember, inkább csoportosan." A szakmán belül nehéz olyan szegmenst találni, ahol egy újonnan alapított kisvállalkozás sikeres tud lenni. Magyarország esetében ez különösen igaz, hiszen a gépészágazatban igen erôs a külföldi cégek jelenléte, amelyek az olcsó, jól képzett munkaerơre támaszkodva nemzetközi kapcsolataiknak, hírnevüknek kihasználásával a régiós és európai autóipar beszállítóivá váltak.

Ha a múködő 15 vállalkozást tekintjük, igen fontos kérdés az is, hogy azok vajon az új tudás hasznosításával létrejött hallgatói vállalkozások-e? A gépészhallgatók tizenöt meglévő vállalkozása között csupán egy olyan akadt, amelyról tulajdonosa úgy nyilatkozott, hogy K+Ftevékenységet folytat, s múködése során már „valamiféle újdonságot” is kifejlesztett, amit a válaszadó a „vállalati és állami tanulmány kategóriába” sorolt. (Ez a vállalkozás BME-s hallgatóé.)

\section{Következtetések}

A felmérés eredménye igazolta előzetes várakozásainkat. A vállalkozásalapítási szándék alapvetốen elég alacsony a gépészhallgatók körében. Még ha van is ilyen szándék, az nem a klasszikus, a technikai újítást elôtérbe helyezô egyetemi spin-off vállalkozások alapítására irányul. Ennek okait véleményem szerint az iparági sajátságokban kell keresni. Kiscégek és pályakezdôk révén, megfelelő múszaki felszereltség és szakmai tapasztalat nélkül nehéz újat alkotni. Ezen kívül a Magyarországon múködő multinacionális cégek is a referenciával már rendelkezô cégekkel lépnek inkább kapcsolatba. Az iparág ilyen értelemben vett „zártsága” nem kedvez az újonnan induló kisvállalkozásoknak.

A felmérés legérdekesebb eredményét, talán a legegyszerúbben úgy lehetne megfogalmazni: „,a jó példa ragadós", hiszen azok, akiknél a családban vállalkozó van, jóval motiváltabbak. A vállalkozásalapítási hajlandóság tehát „tanítható”. Szükség lenne egy összehangolt, integrált cselekvési programra, amely nem feltétlenül - illetve nem kizárólag - a pályázati pénzek növelésével, új finanszírozási források megnyitásával segítené a hallgatói vállalkozások alakítást, hanem az önállóság kultúrájának elterjesztésével, reklámjával.

\section{Lábjegyzet}

${ }^{1}$ A felmérést a 2007 májusában a Pénzügykutató Zrt. - IKU Innovációs Kutató Központ a „VERINEKT - Versenyképes Integrálódás az Európai Kutatási Térségbe” program keretében végezte. A VERINEKT kutatási program vezetóje dr. Inzelt Annamária volt. A cikk alapját képezó kutatásban a szerzón kívül részt vett még Csapó Krisztián is.

${ }^{2}$ Egy másik módszert követtek a témában készült felmérés a VERINEKT-projekt keretében (Bajmóczy - Buzás, 2006). Szegeden az adatfelvételre a Szegedi Tudományegyetem gazdálkodási szakos hallgatói körében, a tanórák keretében került sor. Ez az órákra járok körében lehetôvé tette a közel 100\%-os válaszadást. Ez a módszer több egyetem, különböző karaira kiterjedó felvétel esetén nem követhető.

${ }^{3}$ A legkisebb alatt a 2006/2007. évi hallgatói létszám alapján megállapított sorrendet értem. Ez a SZIE esetében ez 941, a BMF-nél 1193, míg a BME-nél 2876.

\section{Felhasznált irodalom}

Bajmóczy Z. - Buzás N. (2006): Egyetemi hallgatók mint (potenciális) vállalatalapítók. Kutatási jelentés, Szegedi Tudományegyetem

Csapó K. (2008): Amerikai vállalkozásoktatási példák adaptációjának lehetősége Magyarországon. Vezetéstudomány, 39. évf. 1. sz., 43-54. o.

Csapó K. (2007): Vállalkozásoktatás diákvállalkozásokon keresztül - Tapasztalatok a Budapesti Corvinus Egyetemról. Vezetéstudomány, 38. évf. 4. sz., 30-42. o.

Csapó K. - Petheó A. - Szirmai P. (2005): Bepörög vagy kipörög? Figyelő, 49. évf., 49. sz., 54-55. o.

„Diploma 2009” különszám, HVG Kiadó, 2008

Kleinheincz F. (2000): Spin-off vállalkozások, avagy barátkozzunk egy új elnevezéssel. Ipari Szemle. 2000. 4. sz.

Inzelt A. - Csapó K. - Szóke Sz. (2007): Felmérés a felsőoktatásban tanuló hallgatók vállalkozásalapítási motivációjáról - A Budapesti Corvinus Egyetem helyzete (mimeo)

Inzelt A. (2004): "The evolution of University-IndustryGovernment relationships during transition" Research Policy, Vol 33. issue 6-7. 975-995. o.

Szerb L. (szerk.) (2005): Vállalkozásindítás, vállalkozási hajlandóság és a vállalkozási környezeti tényezók alakulása Magyarországon a 2000-es évek elsô felében. Pécsi Tudományegyetem

Szirmai P. - Csapó K. (2006): Gyakorlati vállalkozásoktatás Diákvállalkozások támogatása a Budapesti Corvinus Egyetemen. Új Pedagógiai Szemle, 56. évf. 4. sz. 72-83. o.

Szirmai P. - Csapó K. (2006): From Student to Entrepreneur A Hungarian Experience of Entrepreneurship Teaching. NCGE Working Paper

Papanek G. - Perényi Á. (2006): Spin-offok a fejlett világban és Magyarországon. Európai Tükör, 2006. 1. sz. 81-95. oldal.

Cikk beérkezett: 2009. 8. hó

Lektori vélemény alapján véglegesítve: 2010. 1. hó 